\title{
In vitro antagonistic activity of Trichoderma species against important soil borne pathogens
}

\author{
N.N. Sohaliya*, D.M. Pathak and J.R. Pandya
}

Department of Plant Pathology, College of Agriculture, NAU, Campus Bharuch, Maktampur (Gujarat) India

\section{ARITCLE INFO}

Received : 08.07.2019

Revised : 01.09 .2019

Accepted : 15.09 .2019

KEY WORDS :

Antagonistic activity, Soil borne pathogens
*Corresponding author:

Email : dmpathak@nau.in

\begin{abstract}
The rhizospheric soil samples were collected from different cultivated agricultural fields from Bharuch and Narmada districts and the mycoflora were isolated by serial dilution plate technique. Total eight isolates of Trichoderma viride, Trichoderma harzianum and Trichoderma longibrachiatum were isolated on Potato Dextrose Agar medium. The green coloured colonies were identified by comparing with taxonomic key. They were purified by single spore isolation method and maintained on PDA slants at $4^{0} \mathrm{C}$ in the refrigerator at Department of Pl.Pathology, NMCA, NAU, Navsari. Soil borne Pathogenic fungi viz., Sclerotium rolfsii, Macrophomina phaseolina and Fusarium oxysporum were isolated from the respective diseased plants during field survey in Navsari Agricultural University farm, Navsari. The antagonistic efficacy against test pathogen was evaluated by dual culture plate technique. Among all 8 Trichoderma isolates, The Trichoderma harzianum NCJD8 isolate has showed $24.17 \mathrm{~mm}$ mycelial growth with 73.15 per cent inhibition of Sclerotium rolfsii, where in case of Macrophomina phaseolina, Minimum mycelial growth $(32.67 \mathrm{~mm})$ of test pathogen was recorded in T. longibracheatum NCJD2 isolate with 63.70 per cent inhibition which was statistically at par with $T$. viride NCJD6 $(34.50 \mathrm{~mm})$ with 61.67 per cent inhibition and when it comes to Fusarium oxysporum, T. harzianum NCJD5 showed minimum mycelial growth and highest per cent growth inhibition (75.56\%) with $22.00 \mathrm{~mm}$ colony diameter of the pathogen after seven days of incubation which was statistically at par with isolate $T$. harzianum NCJD1 (72.96\%) with 24.33 mm colony diameter.
\end{abstract}

How to view point the article : Sohaliya, N.N., Pathak, D.M. and Pandya, J.R. (2019). In vitro antagonistic activity of Trichoderma species against important soil borne pathogens. Internat. J. Plant Protec., 12(2) : 127-131, DOI : 10.15740/HAS/IJPP/12.2/127-131, Copyright@ 2019: Hind Agri-Horticultural Society. 